\title{
DETERMINAN KEBERHASILAN PENGOBATAN PADA PASIEN TUBERKULOSIS DI WILAYAH KABUPATEN MUARA ENIM
}

\author{
Faradillah $^{1}$, Misnaniarti ${ }^{2}$, Rizma Adlia Syakurah ${ }^{3}$, Ella Amalia ${ }^{4}$ \\ Prodi Ilmu Kesehatan Masyarakat Fakultas Kesehatan Masyarakat ${ }^{1,2,3}$ \\ Prodi Mikrobiologi Fakultas Kedokteran ${ }^{4}$ \\ Universitas Sriwijaya Palembang \\ Faradillah8551@gmail.com¹, misnaniarti@fkm.unsri.ac.id ${ }^{2}$
}

\begin{abstract}
The high number of tuberculosis (TB) cases in the Muara Enim Regency has encouraged the government and health workers to carry out TB control programs through the community health centers in the region. For this reason, this study was conducted to identify the determinants of the success of tuberculosis treatment in the Muara Enim Regency in terms of input, process, and output. This study used a qualitative design, the informants were selected purposively. Data collection in 2020 through focus group discussions, in-depth interviews with 45 informants, and document review. Data validation used in the form of triangulation of methods and sources. Next, using a thematic data analysis. The results showed that the patient identification process could not be done optimally from the input side due to limited facilities and human resources especially in the highlands and swamps. In terms of process of risk control is still experiencing problems due to patient non-complianceor stop of treatment, andclose contact with TB patient. Meanwhile, in terms of output, namely the Success Rate (SR), which was achieved in 2019, it shows that the success rate varies from $33 \%$ to $100 \%$. Differences in geographic location, human resources, and population affect the SR of the TB control program in Muara Enim. From these findings, it can be concluded that there are still various obstacles faced by the government and health workers as seen from the three determinants that are used as benchmarks for the success of treating tuberculosis patients in Muara Enim.
\end{abstract}

Keywords: Muara Enim, Public Health Center, SITB, Success Rate, Tuberculosis

\begin{abstract}
ABSTRAK
Tingginya kasus tuberkulosis (TB) di Kabupaten Muara Enim mendorong pemerintah dan tenaga kesehatan melalui puskesmas di wilayah tersebut melakukan program penanggulangan TB. Untuk itu, penelitian ini dilakukan untuk mengidentifikasi determinan keberhasilan pengobatan pasien tuberkolosis di wilayah Kabupaten Muara Enim dilihat dari sisi input, proses, dan output. Penelitian ini menggunakan desain kualitatif, informan dipilih secara purposive. Data dikumpulkan tahun 2020 di Kabupaten Muara Enim Provinsi Sumatera Selatan melalui focus group discussion, in-depth interview kepada 45 informan, dan telaah dokumen. Validasi data yang digunakan berupa triangulasi metode dan sumber. Selanjutnya, dianalisis menggunakan metode tematik. Hasil penelitian menunjukkan bahwa dari sisi input, proses identifikasi penderita belum dapat dilakukan secara optimal dikarenakan keterbatasan fasilitas dan sumberdaya manusia terutama di daerah dataran tinggi dan rawa. Dari sisi proses pengendalian resiko juga masih mengalami kendala karena ketidakpatuhan pasien dalam melakukan pengobatan dan pemberhentian sepihak dan kontak erat dengan pasien TB. Sedangkan dari sisi output, yakni Success Rate (SR) masing-masing Puskesmas yang telah dicapai tahun 2019 menunjukkan bahwa tingkat keberhasilan bervariasi mulai dari 33\% sampai dengan 100\% dikarenakan letak geografis, keterbatasan petugas kesehatan, dan jumlah penduduk. Dari temuantemuan tersebut, dapat disimpulkan bahwa masih terdapat berbagai kendala yang dihadapi oleh pemerintah dan tenaga kesehatan dilihat dari tiga determinan yang menjadi tolak ukur keberhasilan pengobatan pasien tuberkulosis di Muara Enim.
\end{abstract}

Kata Kunci: Muara Enim, Puskesmas, SITB, Tingkat Keberhasilan, Tuberkulosis 


\section{PENDAHULUAN}

Tuberkulosis (TB) sampai saat ini masih menjadi permasalahan yang krusial di dunia kesehatan dengan tingkat morbiditas dan mortalitas yang tinggi dan bahkan di beberapa daerah dikenal sebagai permasalahan laten (Fogel, 2015; Paton, et al., 2019). Secara global, melalui Majelis Kesehatan Dunia (The World Health Assembly) penyelesaian kasus TB ditargetkan akan berhasil di tahun 2030 dan nantinya akan dimonitoring dan evaluasi oleh World Health Organization (WHO) di tahun 2035 (World Health Organization, 2014).

Indonesia merupakan salah satu dari delapan negara di Asia dengan kasus TB yang tinggi (World Health Organization, 2018). Untuk itu, Indonesia telah melakukan berbagai upaya penanggulangan TB dengan target yang dicanangkan oleh pemerintah Indonesia dalam mengeliminasi TB diharapkan dapat terwujud di tahun 2035 (Pusat Data dan Informasi, 2018). Di Provinsi Sumatera Selatan pada tahun 2017 terdapat 11.107 kasus TB, menempati peringkat ke7 terbanyak di Indonesia. Kabupaten Muara Enim pada tahun 2019 jumlah kasus TB yaitu 1.737 orang. Kasus tersebut bertambah dalam kurun waktu setahun dimana tahun 2018 sejumlah 1.435 orang dan tahun 2017 sebesar 1.194 orang (Dinas Kesehatan Kabupaten Muara Enim, 2019).

Dalam menaggulangi TB, terdapat dua hal penting yang harus dilakukan yakni diagnosa yang cepat dan pengobatan infeksi TB laten untuk mencegah peningkatan kasus aktif (Harries, et al., 2020). Sehingga, untuk dapat mengakhiri kasus TB keberadaan alat baru (diagnosis, obat-obatan, vaksin), dukungan dari berbagai sektor diluar kementerian kesehatan, yakni pihak swasta dan masyarakat sangat dibutuhkan (Kumar, et al., 2020). Selain itu, keberadaan sistem pengawasan TB yang akurat juga sangat penting dalam upaya penggulangan TB (Schwoebel, 2020).

Untuk itu, maka penelitian ini ditujukan untuk mengidentifikasi determinan keberhasilan pengobatan pasien TB di Muara Enim. Determinan keberhasilan pengobatan pasien $\mathrm{TB}$ tersebut akan dilihat dari teori keberhasilan sebuah program yang terdiri dari tiga aspek yakni input, proses, dan output (Donabedian, 1980).

\section{METODE}

Secara umum, penelitian ini dapat digolongkan sebagai penelitian kualitatif yang dilakukan dengan menggunakan pendekatan deskriptif analitik. Penelitian ini dilaksanakan di sepuluh puskemas yang berada di Kabupaten Muara Enim. Kesepuluh puskesmas tersebut diambil dari lima Puskesmas yang menangani jumlah kasus TB tertinggi dan lima Puskesmas lainnya yang menangani kasus TB terendah. Waktu yang dibutuhkan untuk melaksanakan penelitian ini yakni selama Sembilan Bulan, mulai dari bulan Maret sampai dengan November 2020. Penentuan informan menggunakan teknik purposive dan terdapat 45 orang informan yang dilibatkan dalam penelitian ini yang terdiri dari pihak pemerintah, tenaga kesehatan, dan masyarakat. Pengumpulan data dilakukan melalui Focus Group Discussion (FGD), wawancara mendalam, dan dokumentasi. Data yang terkumpul kemudian dianalisis secara kualitatif mengunakan model analisis tematik yang terdiri dari empat tahapan: memahami data, menyusun kode, mencari tema, dan menyimpulkan. Penelitian ini telah menerima sertifikat dari Komite Etik di Fakultas Kesehatan Masyarakat Universitas Sriwijaya dengan nomor : 318/UN9.1.10/KKE/2020 
HASIL

\section{Input}

\section{SDM/Petugas Kesehatan}

Sumber Daya Manusia (SDM) /petugas TB yang terlibat dalam penanggulangan TB di Puskesmas yaitu dokter, perawat, pengelola $\mathrm{TB}$, dan petugas laboratorium (analis). Selain itu, tim tenaga kesehatan tersebut juga dibantu oleh Lembaga Swadaya Masyarakat (LSM) Muhammadiyah yaitu TB Care Aisyiah dalam menemukan dan mendampingi pasien TB. Dari sisi jumlah, terdapat 22 orang pengelola TB yang tersebar pada seluruh Puskesmas di Kabupaten Muara Enim. Sedangkan untuk analis/petugas laboratorium terdapat 21 orang. Dari informasi yang didapat, ada satu Puskesmas yang analisnya kosong yakni Puskesmas Sumber Mulia.

Kekosongan tenaga analis membuat Puskesmas tersebut kesulitan dalam pemeriksaan sputum. Meskipun dimungkinkan untuk menjalin kerjasama dengan Puskesmas lain yang terdekat, kendala lainnya yang dihadapi yakni jumlah analis di Puskesmas lain juga terbatas dengan beban kerja yang banyak. Sehingga, hal tersebut akan menambah beban kerja analis di puskemas lain. Terlebih lagi jumlah analis yang hanya 1 orang juga membuat pelayanan menjadi tidak maksimal. Karena apabila analis tersebut tidak bekerja dikarenakan ikut pelatihan, cuti, atau sakit, maka pemeriksaan sputum menjadi terhambat.

Meski demikian, sebagian besar tugas dan tanggung jawab yang harus dilaksanakan tim TB Puskesmas baik dari dokter, perawat, pengelola TB dan analis yang terlibat dalam penanggulangan TB telah dilaksanakan dengan baik namun belum maksimal dikarenakan ada beberapa Puskesmas yang kekurangan sumberdaya manusia.

\section{Sarana dan Prasarana}

Penanggulangan TB memerlukan sarana dan prasarana seperti persediaan
Obat Anti Tuberkulosis (OAT), alat transportasi, laboratorium sesuai standar TB, dan Poli TB sesuai standar. Terdapat 6 laboratorium yang sudah sesuai standar untuk pemeriksaan TB, bahkan ada 1 Puskesmas yang sudah memiliki Tes Cepat Molekuler (TCM) sehingga pemeriksaan TB dapat diketahui hasilnya hanya dalam waktu 2 jam. Namun ada 4 Puskesmas belum memenuhi standar pemeriksaan TB, ada yang tidak memiliki wastafel, sehingga untuk pewarnaan sediaan menggunakan kamar mandi, ada yang airnya keruh sehingga harus diendapkan dulu selama 2 hari dan ada juga yang laboratoriumnya bergabung dengan ruang poli pengobatan.

Dari data yang dan informasi yang diperoleh, Obat Anti Tuberkulosis (OAT) senantiasa tersedia di Puskesmas, dengan mengajukan form permintaan ke gudang farmasi Kabupaten dan selalu diberikan sesuai form permintaan tersebut.

Masih ada Poli TB di Puskesmas yang belum memenuhi standar yaitu letak Poli TB seharusnya terpisah dengan ruangan yang lain. Beberapa Poli TB di Puskesmas ada yang bergabung dengan poli lain atau dengan laboratorium. Untuk ketersediaan alat transportasi rata-rata Puskesmas memiliki ambulance, namun kebutuhan Puskesmas yang terletak di aliran sungai membutuhkan transportasi speedboat dimana warganya kebanyakan tinggal di seberang Puskesmas melewati aliran sungai dan Puskesmas yang berada di daerah pegunungan, perkebunan dan hutan membutuhkan motor sebagai alat transportasinya. Sehingga, dari data tersebut dapat dikatakan bahwa dari sarana dan prasarana hal yang menjadi kendala adalah ruang poli, laboratorium dan alat transportasi.

\section{Proses \\ Peningkatan Akses Layanan TB Bermutu \\ Peningkatan semua penyedia layanan TB melalui kerjasama jaringan layanan pemerintah dan swasta serta asuransi kesehatan. Di Puskesmas kolaborasi}


layanan dengan TB-HIV, TB-DM, TBGizi. Membangun Jejaring dengan Dokter Praktek Mandiri, Bidan Praktek Mandiri, fasyankes swasta, Pustu, dan Polindes. Sosialisasi TB ke Lapas, Pesantren, Panti Asuhan, Sekolah. Kerjasama dengan BPJS untuk berobat TB gratis (namun untuk TBHIV, HIV tidak ditanggung BPJS).

Dalam peningkatan penaggulangan TB, maka Puskesmas membuka akses layanan TB bermutu melalui kerjasama dengan berbagai jejaring layanan Public Private Mix (PPM) seperti Dokter Praktek Mandiri (DPM), Bidan Praktek Mandiri (BPM), klinik swasta. Layanan TB bermutu juga melalui kolaborasi pelayanan seperti TBHIV, TB-Gizi dan TB-DM. Puskesmas juga melakukan penemuan aktif berbasis keluarga dan ke masyarakat misalnya ke lapas, panti asuhan, asrama, pesantren, dan sekolah. Puskesmas sudah melakukan peningkatan kerjasama jejaring Public Private Mix (PPM), namun masih terkendala dalam hal pelaporan dari jejaring tersebut. Untuk asuransi kesehatan ditemukan bahwa BPJS sudah menanggung pengobatan TB, sehingga pasien TB dapat berobat secara gratis sampai sembuh.

\section{Pengendalian Faktor Risiko}

Dari data yang diperoleh melalui pasien post TB dan PMO yang merupakan keluarga (istri, anak, atau saudara) ditemukan bahwa terdapat beberapa kendala dalam pengendalian faktor resiko. Permasalahan yang paling sering ditemui yakni faktor lingkungan, terutama rumah, yang kurang sehat. Hal tersebut dikarenakan kurangnya pencahayaan, sirkulasi udara, kandang ternak yang berdekatan dengan rumah, merokok, dan kontak serumah dengan pasien TB, membuat lingkungan rumah menjadi tidak sehat dan penyebaran bakteri penyebab TB menjadi mudah sehingga anggota keluarga pasien TB yang berada dalam satu rumah ikut tertular.

Sehingga, dari data tersebut dapat diketahui bahwa dari sisi pengendalian faktor resiko masih terdapat kendala dalam menjaga kebersihan rumah dan pola hidup sehat. Atau dengan kata lain pemahaman masyarakat akan pentingnya pengendalian faktor resiko masih perlu ditingkatkan.

\section{Output}

Tahun 2019 angka pengobatan lengkap di Kabupaten Muara Enim baru mencapai 67\% angka ini sedikit meningkat dari tahun sebelumnya yaitu hanya 59,3\%, angka ini jauh dari target capaian dimana harusnya semua penderita TB mendapatkan pengobatan secara lengkap, beberapa faktor kecilnya capaian disebabkan karena masih banyak pasien yang drop out minum obat rutin 6 bulan karena tidak kuat dengan efek samping obat, atau karena mulai tergiur dengan pengobatan alternatif sehingga meninggalkan pengobatan medis rutin.

Sedangkan angka keberhasilan pengobatan / Success Rate (SR) penderita Tuberkulosis tahun 2019 beragam di setiap Puskesmas. Puskesmas Muara Emburung dan Pulau Panggung $100 \%$, Puskesmas Muara Enim 96,5 \%, Puskesmas Ujan Mas 97,8 \%, Puskesmas Tanjung Enim 95,9 \%, Puskesmas Tanjung Agung 92,2 \%, Puskesmas Tanjung Raya 87,5 \%, Puskesmas Sumaja Makmur 83,3 \%, Puskesmas Gelumbang 81,2 \% dan Puskesmas Muara Belida 33,3 \%. Capaian harus mencapai $100 \%$ untuk memutus mata rantai penularan TB. Adanya perbedaan capaian target masing-masing Puskesmas disebabkan karena adanya perbedaan letak geografis, jumlah karyawan, dan jumlah penduduk pada wilayah kerja Puskesmas tersebut.

\section{PEMBAHASAN}

\section{Input}

\section{SDM / Petugas Kesehatan}

Ketersediaan dan kualitas sumberdaya manusia merupakan hal yang sangat penting karena tahap identifikasi dan penanganan menjadi kunci dari keberhasilan program penaggulangan $\mathrm{TB}$, semakin cepat dan baik tahap identifikasi dilaksanakan maka semakin berhasil 
program penanggulang $\mathrm{TB}$ tersebut (Colvin, et al., 2019). Program penanggulangan TB akan berhasil apabila upaya yang dilakukan berkelanjutan dan secara aktif menemukan kasus TB, terjadinya pendekatan multisektoral yang lebih kuat untuk mengatasi determinan sosial TB, dan meningkatkan layanan kesehatan yang berpusat pada orang (Chakaya, et al., 2020). Dengan kata lain ketersediaan sumberdaya manusia yang handal menjadi sebuah keharusan.

Temuan penelitian ini menunjukkan bahwa keberadaan sumber daya manusia pendukung program penganggulangan TB masih kurang terutama untuk posisi analis. Padahal menurut Permenkes No.67 Tahun 2016 menyatakan bahwa standar kebutuhan minimal tenaga pelaksana program TB di Puskesmas yakni 1 dokter, 1 perawat/petugas TB dan 1 tenaga laboratorium (analis) (Kemenkes, 2016).

Di Puskesmas Kabupaten Muara Enim rata-rata telah terpenuhi petugas TB dengan tupoksi yang jelas berdasarkan Surat Perintah Tugas (SPT) dari Kepala Puskesmas yaitu dokter bertanggungjawab terhadap penetapan diagnosis penderita TB. Pengelola/Petugas TB bekerja melaksanakan penjaringan kasus, identifikasi kasus, pengambilan dahak, membuat apusan dahak dan memberikan penyuluhan kepada masyarakat. Petugas laboratorium (analis) mempunyai tugas mengumpulkan dahak atau membuat sediaan apus dahak, pewarnaan, membaca sediaan dahak, mengirim hasil bacaan kepada petugas TB dan menyimpan sediaan untuk di crosscheck. Sebagian besar tugas dan tanggung jawab yang harus dilaksanakan tenaga kesehatan yang terlibat dalam program penanggulangan $\mathrm{TB}$ di Puskesmas Kabupaten Muara Enim telah dilaksanakan. Akan tetapi masih ada tugas yang belum dilaksanakan dengan maksimal.

Meski demikian, semestinya petugas kesehatan pengelola TB tidak semata menjadi satu-satunya yang bertanggungjawab penanggulangan $\mathrm{TB}$, melainkan bantuan dari pihak lainnya misalnya petugas kesehatan lain, kader dan Pengawas Menelan Obat (PMO). Karena penangan TB harus melalui kolaborasi antara pihak pemerintah, swasta, dan masyarakat yang selanjutnya didukung dengan manajemen yang baik dan pendanaan yang memadai (Lei, et al., 2015; Abri, et al., 2020).

Ketersediaan tenaga pendukung yang membantu memonitor penderita untuk berobat secara rutin juga terbukti memiliki peranan yang sangat penting dalam keberhasilan pengobatan TB (Izudi, et al., 2020). Selain itu, sumberdaya manusia yang dilibatkan dalam program penanggulangan TB juga harus dipastikan dapat berkomunikasi dan membangun hubungan yang baik dengan penderita (Berg-Johnsen, et al., 2020). Bahkan untuk mempercepat proses penanggulangan kasus TB, pelibatan ahli epidemiologi dalam penanganan kasus TB yang tidak kunjung turun juga perlu dilakukan (Jmaa, et al., 2020).

Dari sisi kualitas, seluruh pengelola TB Puskesmas di Kabupaten Muara Enim telah mendapatkan pelatihan tentang penanggulangan TB. Pelatihan merupakan suatu upaya meningkatkan pengetahuan dan keterampilan petugas dalam rangka meningkatkan mutu dan kinerja petugas. Selain pelatihan, pihak Dinkes Kabupaten Muara Enim melakukan On Job Training (OJT) sehari untuk petugas baru baik dokter atau tenaga kesehatan lainnya agar memahami tata cara penanggulangan TB di Puskesmas. Pelatihan-pelatihan tersebut merupakan hal yang vital karena percepatan program pengendalian TB perlu didukung dengan inovasi dalam penanganan kasus TB, seperti misalnya penerapan Traditional Japanese Moxibustion (TJM) yang telah terbukti berhasil dalam penanganan kasus TB bahkan kasus dengan multi drugs resistant tuberculosis (Young \& Craig, 2020; Abbara, et al., 2020). Bahkan, saat ini para ahli di Global Tuberculosis Network $(G T N)$, melalui konsesus, telah menyusun 
dokumen yang dapat membantu analis dan tenaga kesehatan dalam penanganan dan pengendalian TB (Migliori, et al., 2020).

Pemutahiran informasi, melalui pelatihan akan membantu para petugas dalam melaksanakan pengendalian TB. Meskipun dalam kondisi pandemi, pelatihan melalui mode virtual bisa menjadi alternatif dalam peningkatan petugas penunggalangan TB. Bahkan, pelatihan virtual telah terbukti mampu meningkatkan pemahaman dan membantu petugas untuk memperbarui informasi tentang metode penanganan TB yang termutahir (Sharma, et al., 2020).

\section{Sarana/Prasarana}

Penanggulangan TB di Puskesmas memerlukan sarana dan prasarana seperti alat transportasi yang memadai, laboratorium sesuai standar TB minimal mikroskopis yaitu ruangan laboratorium sudah lengkap bahan dan alat mikroskop, dilengkapi wastafel, instalasi listrik dan air bersih. Poli TB sesuai standar yaitu harus terpisah dengan ruangan yang lain. Persediaan Obat Anti Tuberkulosis yang cukup di farmasi sesuai dengan Permenkes No.67 Tahun 2016 (Kemenkes, 2016)

Berdasarkan penelitian yang dilakukan diketahui bahwa ada 1 Puskesmas yang laboratoriumnya memiliki Tes Cepat Molekuler (TCM) yaitu Puskesmas Tanjung Enim. Puskesmas lainnya masih laboratorium sederhana dan mampu dalam pemeriksaan mikroskopis. Ruangan Laboratorium ada yang sesuai standar dan ada yang belum memenuhi standar pemeriksaan TB, ada yang tidak memiliki wastafel, sehingga untuk pewarnaan sediaan menggunakan kamar mandi, ada yang airnya keruh sehingga harus diendapkan dulu selama 2 hari dan ada juga yang laboratoriumnya bergabung dengan ruang poli pengobatan.

Berdasarkan temuan penelitian yang telah dilaksanakan ditemukan bahwa Puskesmas telah mempunyai jumlah stok obat yang memadai. Obat Anti Tuberkulosis diperoleh melalui Gudang
Farmasi Kabupaten Muara Enim dengan membuat form permintaan obat. Poli TB di Puskesmas masih ada yang belum memenuhi standar yaitu letak Poli TB seharusnya terpisah dengan ruangan yang lain. Namun beberapa Poli TB di Puskesmas masih ada yang bergabung dengan poli lain atau dengan laboratorium.

Alat transportasi adalah hal penting dalam eksekusi pelaksanaan program, ada Puskesmas yang telah lengkap alat transportasi seperti motor, ambulance, dan mobil puskesmas keliling. Namun ada juga yang kurang atau tidak ada alat transportasi yang memadai. Fasilitas transportasi Puskemas hendaknya disesuaikan dengan kebutuhan daerah masing-masing, misalnya daerah pegunungan, hutan dan perkebunan dengan akses jalan sempit lebih membutuhkan motor, dan daerah aliran sungai membutuhkan speedboat sehingga tugas program penanggulangan TB dapat mencapai target.

Keberadaan jumlah dan kualitas sarana kesehatan dan sarana penunjang lainnya akan sangat memengaruhi keberhasilan penanggulangan TB. Hal tersebut karena jumlah dan kualitas sarana kesehatan dan penunjangnya akan menentukan kecepatan pendeteksian dan kualitas penanganan sehingga mempengaruhi hasil dari program pengendalian TB (Stallworthy, et al., 2020). Kecepatan pendeteksian penderita menjadi kunci utama dalam keberhasilan penanganan kasus TB (Duarte, et al., 2018). Selain ketersediaan OAT, keberadaan vaksin TB juga terbukti sangat penting dalam upaya pencegahan (Awad, et al., 2020).

Permasalahan keterbatasan dana untuk penanganan kasus TB, faktor ekonomi masyarakat, biaya perawatan, dan rendahnya pengetahuan terhadap TB yang dimiliki pasien dan keluarga pasien merupakan permasalahan yang sering dialami di negara-negara berkembang (Wynne, et al., 2014; Wilson, et al., 2016; Foster, et al., 2015). Sehingga, dalam penanganan kasus TB sebagai penyakit 
menular, keterlibatan politik dalam penyusunan anggaran menjadi sangat penting, karena dengan dukungan politik dan pendanaan yang kuat maka penanganan TB akan menjadi lebih mudah (Schito, et al., 2017).

Proses

\section{Peningkatan Akses Layanan TB Bermutu}

Puskesmas di Kabupaten Muara Enim sudah membangun akses layanan TB bermutu, melalui kerjasama dengan berbagai jejaring layanan (Public Private Mix) yaitu kerjasama dengan BPM/ Bidan Praktek Mandiri, DPM / Dokter Praktek Mandiri serta Fasyankes swasta lainnya, namun kendalanya adalah pelaporan yang kurang dari jejaring tersebut.

Layanan TB bermutu juga melakukan kolaborasi pelayanan seperti TB-HIV, TBGizi dan TB-DM. Puskesmas juga melakukan penemuan aktif berbasis keluarga dan masyarakat misalnya lapas, panti asuhan, asrama, pesantren dan sekolah. Asuransi kesehatan dalam hal ini adalah BPJS sudah menanggung pengobatan TB, sehingga pasien dapat berobat gratis sampai sembuh. Sesuai dengan penelitian dari Haq Z tahun 2012 menyatakan bahwa ada dua komponen penting dalam strategi Stop-TB yaitu PPM/Public Private Mix dan ACSM /Advocacy, Communication, and Social Mobilisation (Z Haq, 2012).

\section{Pengendalian Faktor Risiko}

Faktor risiko terkena TB yaitu lingkungan rumah tidak sehat, udara tidak bersih, tidak masuk sinar matahari ke dalam rumah, ventilasi kurang, memelihara hewan ternak yang berdampingan dengan rumah yang menyebabkan udara terkontaminasi, tertular satu rumah dengan pasien TB dan merokok. Gejala awal yang dirasakan pada TB Paru adalah batuk terusmenerus lebih dari 2 minggu, batuk berdarah, nafsu makan menurun dan benjolan yang nyeri pada TB ekstra paru.
Pengendalian faktor risiko TB yaitu dengan melakukan Perilaku Hidup Bersih dan Sehat (PHBS), pencegahan infeksi bagi populasi rentan dengan imunisasi Bacillus Calmette Guerin (BCG), pemakaian Alat Pelindung Diri (APD) yang benar (masker), etika batuk yang benar, memperhatikan kondisi lingkungan yang sehat, tidak bergantian peralatan pribadi, dan kepatuhan menelan obat secara rutin dan taat aturan. Pengobatan TB teratur hanya membutuhkan waktu 6 bulan, namun karena ketidakpatuhan menyebabkan menambah waktu penyembuhan lebih lama lagi, hal ini disebabkan pasien sudah merasa sembuh di bulan ke-3 sehingga tidak melanjutkan pengobatan dan terlupa menelan obat. Peran Pengawan Menelan Obat sangat penting dalam mendukung kesembuhan pasien TB.

Masyarakat di daerah Sunda, masih kurang pemahamannya tentang penyebaran TB kepada anak sehingga mereka hanya berserah kepada kehendak Tuhan (Rakhmawati, et al., 2019). Hapir keseluruhan $(96 \%)$ kasus kematian anakanak akibat TB banyak yang terjadi di negara berkembang dikarena anak-anak tersebut tidak mendapatkan penanganan atau perawatan TB (Dodd, et al., 2017). Sampai saat ini tingkat penderita TB di usia anak-anak masih sangat tinggi di dunia, yakni kira-kita 20 juta kasus tiap tahun (Reuter, et al., 2020). Untuk itu, membangun kepercayaan masayarakat terhadap pengobatan medis perlu dilakukan oleh tim penanggulangan TB (Arsenault, et al., 2019).

Selain itu, untuk kasus di Indonesia, keterlambatan diagnosis sering terjadi karena proses penanganan yang masih kompleks, tingkat pendidikan pasien/keluarga pasien, faktor ekonomi dan ketidaktersediaan jaminan kesehatan yang membuat pasien enggan untuk memeriksakan kondisi kesehatan mereka (Lestari, et al., 2020). Sehingga, edukasi dari tim penaggulangan TB menjadi sangat dibutuhkan untuk meningkatkan pemahaman masyarakat akan pentingnya 
perawatan medis dan informasi mengenai penggratisan biaya pengobatan TB.

Lebih lanjut, dalam proses penanganan kasus TB dalam situasi pandemik Covid-19 saat ini yang juga berhubungan dengan masalah pernafasan, regulasi daerah yang mampu mendukung program penanggulangan TB menjadi sangat penting untuk menjamin keberhasilan program tersebut (Fei, et al., 2020). Keberadaan pandemik Covid-19 terbukti meningkatkan jumlah kematian akibat kurangnya akses pelayanan kesehatan karena terfokus untuk penanganan pasien Covid-19 terutama di Negara-negara berkembang yang memiliki fasilitas dan tenaga kesehatan terbatas (Hogan, et al., 2020; Pharm, et al., 2020). Untuk itu diperlukan sebuah regulasi dan kesiapan sumberdaya manusia serta sarana dan prasarana dalam menghadapi pandemik sekaligus menangani penderita TB sehingga tidak terjadi keterlambatan penanganan (Klinton, et al., 2020).

\section{Output}

Output berupa Angka Keberhasilan Pengobatan / Success Rate (SR) pada Puskesmas di Kabupaten Muara Enim tahun 2019 beragam mulai 33\% sampai dengan $100 \%$. Adanya perbedaan capaian masing-masing Puskesmas karena adanya perbedaan letak geografis, SDM dan jumlah penduduk. Sedangkan total angka keberhasilan pengobatan penderita Tuberkulosis tahun 2019 di Kabupaten Muara Enim mencapai 92,6 \% angka ini meningkat tipis dari capaian tahun lalu yang mencapai $92,2 \%$. Walau cukup tinggi tapi masih jauh dibawah target eliminasi TB, dimana target capaian harus mencapai $100 \%$. Dengan tingkat kesembuhan pengobatan mencapai $100 \%$ maka dapat memutus rantai penularan $\mathrm{TB}$ dan dengan demikian dapat menurunkan insiden TB di masyarakat. Output yang baik tidak terlepas dari keberhasilan input dan proses, semuanya harus berkolaborasi secara efektif sehingga hasilnya sesuai yang diharapkan.
Menurut hasil studi (Wahab, 2002) menyatakan bahwa guna mencapai output yang efektif dalam upaya penanganan TB maka semua aspek cara penanggulangan TB harus dilakukan. Hal ini sejalan dengan penelitian (Murti, 2010) yang dilakukan di Eks Keresidenan Surakarta menunjukkan hasil penatalaksanaan program $\mathrm{TB}$ belum mencapai target yang diharapkan karena rendahnya partisipasi dokter, Rumah Sakit, dan tenaga kesehatan lainnya dalam penemuan kasus dan diagnosis kasus TB. Jadi seluruh komponen input maupun proses harus berjalan efektif sehingga menghasilkan output yang diharapkan. Secara umum keberhasilan kebijakan program penanggulangan TB pada Puskesmas di Kabupaten Muara Enim sudah baik namun belum maksimal sesuai dengan strategi eliminasi TB dikarenakan masih ada input dan proses belum berjalan optimal.

Penelitian ini telah dilaksanakan sesuai prosedur ilmiah yang berlaku, namun masih memiliki keterbatasan. Pertama, kondisi demografi yang beragam mulai dari daratan pegunungan semende sampai daerah rawa menuju aliran sungai musi dengan jarak tempuh 3 sampai dengan 4 jam menuju lokasi, sehingga memerlukan waktu lama di perjalanan. Kedua, adanya kendala dalam menentukan waktu wawancara kepada informan, terutama mencocokkan jadwal dengan informan dikarenakan banyak agenda Dinas Luar (DL) dan lagi wabah Covid-19 sehingga petugas Work from Home (WFH). Akhirnya ada informan yang pelaksanaan wawancaranya melalui telepon. Jadwal FGD (Focus Group Disscussion) yang terlambat dikarenakan menunggu peserta FGD yang jarak tempuhnya jauh dari Kota Muara Enim (tempat FGD yang dijadwalkan). Selain itu, jawaban dari informan terkadang subjektif sehingga menyulitkan peneliti untuk menyimpulkan suatu kondisi di lapangan sehingga berkali-kali mentelaah informasi yang didapatkan dari berbagai sudut pandang (triangulasi). 
Namun, keberhasilan penanganan TB juga sebaiknya mempertimbangkan faktor kualitas kehidupan penderita, karena tidak sedikit penderita yang biasanya dikucilkan. Sehingga peran serta pemerintah melalui pelaksana program penanggulangan $\mathrm{TB}$ mampu memberikan pengetahuan kepada masyarakat untuk membangun reformasi sosial-budya pandangan masyarakat terhadap penderita TB dan memberikan insentf untuk mendukung kualitas hidup penderita menjadi hal yang vital untuk dipertimbangkan oleh pemerintah (Aggarwal, 2019).

\section{KESIMPULAN}

Berdasarkan hasil penelitian tersebut dapat diketahui bahwa petugas penggulangan TB telah berupaya melaksanakan tugas mereka dengan baik, namun masih terdapat beberapa halangan yaitu SDM kesehatan yang kurang yaitu analis maupun sarana/prasarana seperti Poli TB, laboratorium maupun alat transportasi, terutama di daerah dataran tinggi pegunungan dan rawa, yang membuat upaya penanggulangan TB tidak bisa dilakukan secara optimal sehingga tidak mencapai target yang diharapkan.

Output berupa Success Rate / SR (angka keberhasilan pengobatan) beragam karena letak geografis, SDM, dan jumlah penduduk. SR yang dicapai yaitu dari $33 \%$ sampai dengan $100 \%$.

\section{UCAPAN TERIMA KASIH}

Terima kasih kepada Dinas Kesehatan Kabupaten Muara Enim dan anggota DPRD Komisi IV yang telah memfasilitasi dalam penelitian ini.

\section{DAFTAR PUSTAKA}

Abbara, A. et al., (2020). The challenges of tuberculosis control in protracted conflict: The case of Syria. International Journal of Infectious Diseases, Volume 90, pp. 53-59.
Abri, S. A. et al., (2020). Tools to implement the World Health Organization End TB Strategy: Addressing common challenges in high and low endemic countries. International Journal of Infectious Diseases, Volume 92, pp. S60-S68.

Aggarwal, A. N., (2019). Quality of life with tuberculosis. Journal of Clinical Tuberculosis and Other Mycobacterial Diseases, Volume 17, p. 100121.

Arsenault, C., Roder-DeWan, S. \& Kruk, M. E., (2019). Measuring and improving the quality of tuberculosis care: A framework and implications from the Lancet Global Health Commission. Journal of Clinical Tuberculosis and Other Mycobacterial Diseases, Volume 12, p. 100112.

Awad, S. F., Critchley, J. A. \& AbuRaddad, L. J., (2020). Epidemiological impact of targeted interventions for people with diabetes mellitus on tuberculosis transmission in India: Modelling based predictions. Epidemics, Volume 30, p. 100381.

Berg-Johnsen, A., Hådem, S. O., Tamrakar, D. \& Harstada, I., (2020). A questionnaire of knowledge, attitude and practices on tuberculosis among medical interns in Nepal. Journal of Clinical Tuberculosis and Other Mycobacterial Diseases, Volume 20, p. 100173 .

Chakaya, J. M., Harriesa, A. D. \& Marks, G. B., (2020). Ending tuberculosis by 2030-Pipe dream or reality?. International Journal of Infectious Diseases, Volume 92, pp. S51-S54.

Colvin, C. et al., (2019). Quality of TB services assessment: The unique contribution of patient and provider perspectives in identifying and addressing gaps in the quality of TB services. Journal of Clinical Tuberculosis and Other Mycobacterial Diseases, Volume 17, p. 100117. 
Dinas Kesehatan Kabupaten Muara Enim, (2019). Profil Dinas Kesehatan Kabupaten Muara Enim Tahun 2019. Muara Enim: Dinas Kesehatan Kabupaten Muara Enim .

Dodd, P. J. et al., (2017). The global burden of tuberculosis mortality in children: a mathematical modelling study. The Lancet Global Heath, 5(9), pp. e898e906.

Donabedian, (1980). The Definition of Quality and Approach Its Assessment. Ann Arbor Michigan: Health Administration Press.

Duarte, R. et al., (2018). Tuberculosis, social determinants and comorbidities (including HIV). Pulmonology, 24(2), pp. 115-119.

Fei, H. et al., (2020). The impact of the COVID-19 epidemic on tuberculosis control in China. The Lancet Regional Health - Western Pacific, Volume 3, p. 100032.

Fogel, N., (2015). Tuberculosis: A disease without boundaries. Tuberculosis, pp. 527-531.

Foster, N. et al., (2015). The economic burden of TB diagnosis and treatment in South Africa. Social Science \& Medicine, Volume 130, pp. 42-50.

Harries, A. D. et al., (2020). The growing importance of tuberculosis preventive therapy and how research and innovation canenhance its implementation on the ground. Tropical Medicines and Infectious Deseases, 5(61), pp. 1-16.

Hogan, A. B. et al., (2020). Potential impact of the COVID-19 pandemic on HIV, tuberculosis, and malaria in low-income and middle-income countries: a modelling study. The Lance Global Health, 8(9), pp. e1132-e1141.

Izudi, J., Tamwesigire, I. K. \& Bajunirwe, F., (2020). Treatment supporters and level of health facility influence completion of sputum smear monitoring among tuberculosis patients in rural Uganda: A mixed- methods study. International Journal of Infectious Diseases, Volume 91, pp. 149-155.

Jmaa, M. B. et al., (2020). The ongoing challenge of Pulmonary Tuberculosis in Southern Tunisia: A review of a 22-year period. Respiratory Medicine and Research, Volume 77, pp. 67-71.

Klinton, J. S., Oga-Omenka, C. \& Heitkamp, P., (2020). TB and COVID - Public and private health sectors adapt to a new reality. Journal of Clinical Tuberculosis and Other Mycobacterial Diseases, Volume 21, p. 100199.

Kumar, A. M. et al., (2020). What is operational research and how can national tuberculosis programmes in low- and middle-income countries use it to end TB?. Indian Journal of Tuberculosis, 67(4), pp. S23-S32.

Lei, X. et al., (2015). Public-private mix for tuberculosis care and control: a systematic review. International Journal of Infectious Diseases, Volume 34, pp. 20-32.

Lestari, B. W. et al., (2020). Patient pathways and delays to diagnosis and treatment of tuberculosis in an urban setting in Indonesia. The Lancet Regional Health-Western Pacific, Volume 5, p. 100059.

Migliori, G. B. et al., (2020). MDR/XDRTB management of patients and contacts: Challenges facing the new decade. The 2020 clinical update by the Global Tuberculosis Network. International Journal of Infectious Diseases, Volume 92, pp. S15-S25.

Paton, N. I. et al., (2019). Diagnosis and management of latent tuberculosis infection in Asia: Review of current status and challenges. International Journal of Infectious Diseases, Volume 87, pp. 21-29.

Pharm, C. O.-O. B. et al., (2020). Commentary: Lessons from the COVID-19 global health response to inform TB case finding. Healthcare, p. 100487. 
Pusat Data dan Informasi, (2018). Tuberkulosis. Jakarta: Pusat Data dan Informasi kementerian Kesehatan Republik Indonesia.

Rakhmawati, W., Nilmanat, K. \& Hatthakit, U., (2019). Moving from fear to realization: Family engagement in tuberculosis prevention in children living in tuberculosis Sundanese households in Indonesia. International Journal of Nursing Sciences, 6(3), pp. 272-277.

Reuter, A., Seddon, J. A., Marais, B. J. \& Furin, J., (2020). Preventing tuberculosis in children: A global health emergency. Paediatric Respiratory Reviews, Volume 36, pp. 44-51.

Schito, M., Hanna, D. \& Zumla, A., (2017). Tuberculosis eradication versus control. International Journal of Infectious Diseases, Volume 56, pp. 10-13.

Schwoebel, V., (2020). Surveillance of tuberculosis. Indian Journal of Tuberculosis, 67(4), pp. S33-S42.

Sharma, S. K., Mandal, A. \& Mishra, M., (2020). Effectiveness of m-learning on knowledge and attitude of nurses about the prevention and control of MDR TB: A quasi-randomized study. Indian Journal of Tuberculosis, p. in press.

Stallworthy, G., Dias, H. M. \& Pai, M., (2020). Quality of tuberculosis care in the private health sector. Journal of clinical tuberculosis and other mycobacterial diseases, Volume 20, p. 100171.

Wilson, J. W. et al., (2016). Tuberculosis patient and family education through videography in El Salvador. Journal of Clinical Tuberculosis and Other Mycobacterial Diseases, Volume 4, pp. 14-20.

World Health Organization, (2014). The End TB Strategy: Global strategy and targets for tuberculosis prevention, care and control after 2015. Genewa: World Health Organization.
World Health Organization, (2018). Global Tuberculosis Report 2018. Genewa: World Health Organization.

Wynne, A., Richter, S., Banura, L. \& Kipp, W., (2014). Challenges in tuberculosis care in Western Uganda: Health care worker and patient perspectives. International Journal of Africa Nursing Sciences, Volume 1, pp. 6-10.

Young, M. \& Craig, J., (2020). Urgent global action is needed on multi drugresistant tuberculosis (MDR-TB) can small cone moxa contribute to a global response?. European Journal of Integrative Medicine, Volume 37, p. 101072.

Z Haq, W. K., Setia. (2012). Promoting Public Private Mix for TB DOTS: a multi country study from the WHO Eastern Mediterranean Region. EMHJ-Eastern Mediterranean Health Journal, 18(5), 7 